\title{
Branchiibius hedensis gen. nov., sp. nov., an actinobacterium isolated from a Japanese codling (Physiculus japonicus)
}

\author{
Correspondence \\ Satoshi Sugimoto \\ sugimoto-s@mercian.co.jp
}

\author{
Satoshi Sugimoto, ${ }^{1}$ Taira Kato, ${ }^{2}$ Masashi Ito, ${ }^{1}$ Noriaki Sakata, ${ }^{1}$ \\ Toshio Tsuchida, ${ }^{1}$ Atsuko Matsumoto ${ }^{3}$ and Yoko Takahashi ${ }^{3}$
${ }^{1}$ Mercian Corporation, Bioresource laboratories, 1808 Nakaizumi, Iwata, Shizuoka 438-0078, Japan
${ }^{2}$ Mercian Corporation, Biotechnical Development Center, 1808 Nakaizumi, Iwata, Shizuoka 438-0078, Japan
${ }^{3}$ Kitasato Institute for Life Sciences, Kitasato University, 5-9-1 Shirokane, Minato-Ku, Tokyo 108-8641, Japan

A novel, Gram-stain-positive bacterial strain, Mer $29717^{\top}$, was isolated from the branchia (gills) of a Japanese codling, Physiculus japonicus, collected from bottom waters of Suruga Bay in Shizuoka, Japan. Phylogenetic analysis based on 16S rRNA gene sequences indicated that this strain represents a distinct lineage within the family Dermacoccaceae and was related most closely to members of the genera Demetria and Yimella. It shared highest 16S rRNA gene sequence similarity (95.1\%) with Yimella lutea YIM 45900 ${ }^{\top}$. Strain Mer $29717^{\top}$ contained MK-

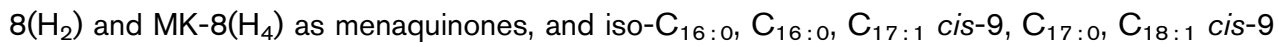
and $\mathrm{C}_{19: 1}$ cis-10 were the major cellular fatty acids. The cell-wall peptidoglycan of strain Mer $29717^{\top}$ was composed of L-Lys, D-Ser, L-Ser, Gly, D-Glu and D-Ala. Polar lipids were phosphatidylinositol, phosphatidylglycerol, diphosphatidylglycerol and one unidentified phospholipid. Mycolic acids were not detected. The $\mathrm{G}+\mathrm{C}$ content of the DNA of strain Mer $29717^{\top}$ was $68 \mathrm{~mol} \%$. On the basis of differential chemotaxonomic, physiological and biochemical data, strain Mer $29717^{\top}$ is considered to represent a novel species of a new genus, for which the name Branchiibius hedensis gen. nov., sp. nov. is proposed. The type strain of Branchiibius hedensis is Mer $29717^{\top}$ (=NBRC $\left.106121^{\top}=\operatorname{DSM} 22951^{\top}\right)$.
The description of an increasing diversity of actinobacteria has led to the discovery of secondary metabolites that can be applied in the pharmaceutical industry. In this regard, we have used soil and plant material as sources and have isolated over 30000 actinobacteria. Over the past decade, many novel bioactive secondary metabolites discovered from marine actinobacteria have been reported (Lam, 2006), and these metabolites may have pharmaceutical potential (Fiedler et al., 2005; Jensen et al., 2005; Fenical \& Jensen, 2006). Due to the attractiveness of marine sources for biologically divergent micro-organisms, we have been seeking to expand the diversity of our library. Here we describe the taxonomic characterization and classification of a novel actinobacterial strain, Mer $29717^{\mathrm{T}}$, isolated from a marine resource. Phylogenetic analysis shows that this strain forms a monophyletic branch in the family Dermacoccaceae (Stackebrandt \& Schumann, 2000).

The GenBank/EMBL/DDBJ accession number for the 16S rRNA gene sequence of Mer $29717^{\top}$ is AB520822.

Two supplementary figures are available with the online version of this paper.
Strain Mer $29717^{\mathrm{T}}$ was isolated from the branchia of a Japanese codling, Physiculus japonicus, which was collected from bottom waters of Suruga Bay in Shizuoka prefecture, Japan. The sample was treated with $70 \%$ ethanol (v/v) for $1 \mathrm{~min}$ to sterilize the surface, cut into small pieces (approx. $3 \times 3 \mathrm{~mm}^{2}$ ) and ground with a pestle in sterilized PBS. This suspension was diluted appropriately and spread onto isolation plates. The medium used for isolation of strain Mer $29717^{\mathrm{T}}$ was HVA medium (Hayakawa \& Nonomura, 1987). The isolation plates were incubated for 21 days at $28{ }^{\circ} \mathrm{C}$. Colonies of actinomycetes on isolation plates were transferred to sterilized International Streptomyces Project (ISP) medium 2 (Difco) and maintained at $28{ }^{\circ} \mathrm{C}$.

Colony morphology, size and colour were examined by using cultures grown for 2 weeks on ISP medium 2. Gramstaining was carried out by using a standard Gram reaction kit (BD). Salt tolerance was tested in ISP medium 2 supplemented with $0,4,7,10$ and $13 \%(w / v) ~ N a C l$ after 2 weeks of incubation at $28{ }^{\circ} \mathrm{C}$. Growth at $5,10,15,20,25$, $28,30,37,42,45$ and $50{ }^{\circ} \mathrm{C}$ was examined on ISP medium 2. Cell motility and morphology were studied by using 
phase-contrast and scanning electron microscopy (model JSM-5600; JEOL), respectively. Cells for morphological observation were cultured for 2 days at $28{ }^{\circ} \mathrm{C}$ on R2A medium (Difco). Enzyme profiling was performed with API ZYM microtubes (bioMérieux), according to the manufacturer's instructions. After $12 \mathrm{~h}$ of incubation at $37^{\circ} \mathrm{C}$, data were recorded both as positive/negative and on a scale of $0-5$. Other cultural characteristics were determined according to the methods of the ISP (Shirling \& Gottlieb, 1966). Chemotaxonomic characteristics were determined by using cells grown in trypticase soy broth (Difco) at $28{ }^{\circ} \mathrm{C}$ and 220 r.p.m. for 4 days. Respiratory quinones were extracted with chloroform/methanol $(2: 1$, $\mathrm{v} / \mathrm{v})$, separated on preparative TLC plates and determined by LC-MS with an HP Agilent 6320 Ion Trap (Agilent Technologies). The $\mathrm{G}+\mathrm{C}$ content of the DNA was determined as described by Katayama-Fujiwara et al. (1984) and Katoh et al. (1983). The profile of whole-cell fatty acid methyl esters was determined by using the MIDI Sherlock Microbial Identification system (Microbial ID) (Miller, 1982). Fatty acids unidentified by this system $\left(\mathrm{C}_{16: 1}\right.$ trans- 9 and $\mathrm{C}_{19: 1}$ cis-10) were analysed via GC-MS (PerkinElmer). Whole-cell sugars were analysed as described by Yang et al. (2005). Cell walls were isolated and purified according to the method of Schleifer \& Kandler (1972). The amino acid composition of cell-wall hydrolysates (Becker et al., 1964) was analysed by HPLC as described by Kawasaki et al. (2007). The $N$-acyl type of muramic acid was determined by the colorimetric method of Uchida \& Aida (1977). The presence of mycolic acids was investigated by using the TLC method of Minnikin et al. (1975) and phospholipids were analysed as described by Minnikin et al. (1984).

DNA for 16S rRNA gene sequence analysis was prepared by using an InstaGene matrix (Bio-Rad). The 16S rRNA gene was amplified by PCR with a forward primer corresponding to positions $9-27$ and a reverse primer corresponding to

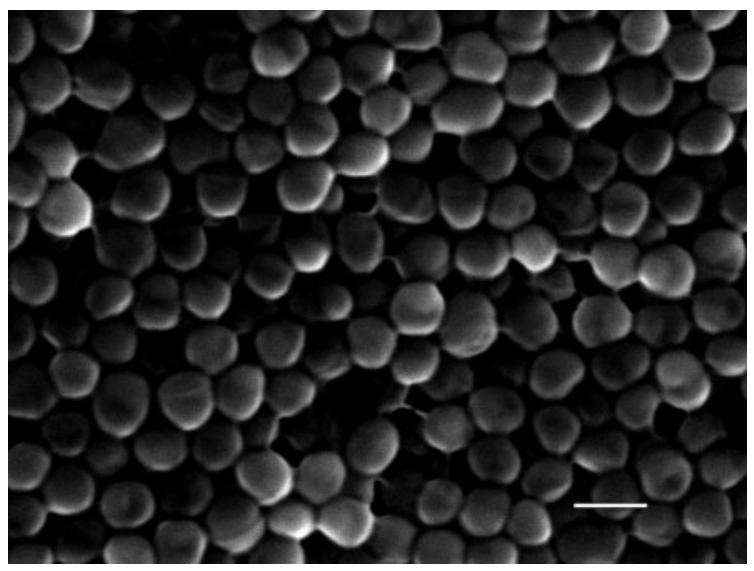

Fig. 1. Scanning electron micrograph of cells from a 2-day-old culture of strain Mer $29717^{\top}$ grown on R2A medium at $28^{\circ} \mathrm{C}$. Bar, $1 \mu \mathrm{m}$. positions 1541-1525 (Escherichia coli numbering system; Weisburg et al., 1991) and was sequenced by using the BigDye Terminator version 3.1 cycle sequencing kit (Applied

Table 1. Cellular fatty acid compositions of strain Mer $29717^{\top}$ and the type strains of related species

Strains: 1 , Mer $29717^{\mathrm{T}}$; 2, Demetria terragena HKI $0089^{\mathrm{T}}$ (data from Groth et al., 1997); 3, Dermacoccus nishinomiyaensis DSM $20448^{\mathrm{T}}$ (Stackebrandt et al., 1995); 4, Kytococcus sedentarius $\mathrm{HO}-9042^{\mathrm{T}}$ (Stackebrandt et al., 1995); 5, Yimella lutea YIM $45900^{\mathrm{T}}$ (Tang et al., 2010); 6, Luteipulveratus mongoliensis MN07-A $370^{\mathrm{T}}$ (Ara et al., 2010). Values are percentages of the total fatty acids;,$-<0.1 \%$, not detected or not reported.

\begin{tabular}{|c|c|c|c|c|c|c|}
\hline Fatty acid & 1 & 2 & 3 & 4 & 5 & 6 \\
\hline \multicolumn{7}{|c|}{ Saturated straight-chain } \\
\hline $\mathrm{C}_{14: 0}$ & 0.1 & 0.5 & - & - & 3.0 & - \\
\hline $\mathrm{C}_{15: 0}$ & 3.1 & 1.5 & - & 10.6 & 1.0 & 0.7 \\
\hline $\mathrm{C}_{16: 0}$ & 5.1 & 9.8 & 1.6 & 2.8 & 5.7 & 2.1 \\
\hline $\mathrm{C}_{17: 0}$ & 8.5 & 13.9 & 1.1 & 22.2 & 0.5 & $6.3^{*}$ \\
\hline $\mathrm{C}_{18: 0}$ & 1.1 & 14.2 & - & - & - & 1.6 \\
\hline $\mathrm{C}_{19: 0}$ & 0.3 & 2.2 & - & - & - & - \\
\hline \multicolumn{7}{|c|}{ Unsaturated straight chain } \\
\hline $\mathrm{C}_{15: 1}$ & - & - & 1.6 & 2.6 & - & 0.4 \\
\hline $\mathrm{C}_{16: 1}$ cis -9 & - & - & - & - & 3.3 & 1.5 \\
\hline $\mathrm{C}_{16: 1}$ trans -9 & 0.3 & 3.4 & 7.2 & 3.1 & - & - \\
\hline $\mathrm{C}_{17: 1}$ cis-9 & 25.2 & - & - & - & 1.0 & 7.3 \\
\hline $\mathrm{C}_{18: 1}$ cis- 9 & 15.8 & 25.2 & 4.6 & - & 2.0 & 1.2 \\
\hline $\mathrm{C}_{18: 1} 2-\mathrm{OH}$ & - & - & - & - & 1.6 & - \\
\hline $\mathrm{C}_{19: 1}$ cis-10 & 5.0 & - & - & - & - & - \\
\hline $\mathrm{C}_{19: 1}$ unknown $1 \dagger$ & 1.4 & - & - & - & - & - \\
\hline \multicolumn{7}{|l|}{ Branched } \\
\hline iso- $\mathrm{C}_{13: 0}$ & - & - & - & - & 4.2 & - \\
\hline anteiso- $\mathrm{C}_{13: 0}$ & - & - & - & - & 2.4 & - \\
\hline iso- $\mathrm{C}_{14: 0}$ & 0.3 & - & - & - & 0.5 & 0.8 \\
\hline iso- $\mathrm{C}_{15: 0}$ & - & 1.9 & 10.3 & 2.7 & 35.2 & 0.4 \\
\hline anteiso- $\mathrm{C}_{15: 0}$ & - & - & - & 1.2 & 12.1 & 0.4 \\
\hline iso- $\mathrm{C}_{15: 1}$ & - & - & 1.5 & - & - & - \\
\hline iso- $\mathrm{C}_{16: 0}$ & 22.3 & 7.4 & 6.0 & 2.0 & 4.8 & 45.8 \\
\hline iso- $\mathrm{C}_{16: 1}$ & - & - & 1.8 & - & 0.5 & 7.6 \\
\hline iso- $\mathrm{C}_{17: 1}$ & - & - & 18.0 & 10.6 & - & - \\
\hline anteiso- $\mathrm{C}_{17: 1}$ & - & - & 2.5 & - & 0.8 & 2.5 \\
\hline iso- $\mathrm{C}_{17: 0}$ & - & 6.2 & 17.8 & 8.1 & 5.5 & 1.1 \\
\hline anteiso- $\mathrm{C}_{17: 0}$ & 0.6 & 9.9 & 17.1 & 29.8 & 11.1 & 7.9 \\
\hline 9-Methyl C $16: 0$ & - & - & - & - & 2.0 & - \\
\hline 10-Methyl $C_{16: 0}$ & - & - & - & - & - & 2.0 \\
\hline 10-Methyl $C_{17: 1}$ & 2.8 & - & - & - & - & - \\
\hline 10-Methyl $C_{17: 0}$ & 2.8 & - & - & - & - & 6.4 \\
\hline 10-Methyl $C_{18: 0}$ & 0.7 & - & - & - & - & 0.4 \\
\hline iso- $\mathrm{C}_{18: 0}$ & - & - & 2.4 & - & - & 2.4 \\
\hline anteiso- $\mathrm{C}_{18: 0}$ & 3.5 & - & - & - & - & - \\
\hline$t 19 \ddagger$ & - & 1.8 & - & - & - & - \\
\hline
\end{tabular}

*Ara et al. (2010) listed two components as $\mathrm{C}_{17: 0}$, representing 4.0 and $2.3 \%$ of the total. The identity of these components is not clear. $\dagger$ The double bond position and cis/trans isomer were not identified. $\ddagger$ Identified by Groth et al. (1997) as 10-methoxyl octadecanoic acid. 
Biosystems) on an automatic sequence analyser (3100 DNA analyser; Applied Biosystems). Strains related closely to strain Mer $29717^{\mathrm{T}}$ were identified by performing sequence database searches with the BLAST program (Altschul et al., 1990) and the EzTaxon server (Chun et al., 2007). Sequence data for related strains were retrieved from GenBank and used for detailed phylogenetic analysis. The CLUSTAL X program (Thompson et al., 1997) was used to align the $16 \mathrm{~S}$ rRNA gene sequences. Phylogenetic analyses were performed by using the neighbour-joining (Saitou \& Nei, 1987), maximum-parsimony (Fitch, 1971) and maximumlikelihood (Felsenstein, 1981) methods. A phylogenetic tree was reconstructed with the neighbour-joining method of Saitou \& Nei (1987) from $K_{\text {nuc }}$ values (Kimura, 1980) by using MEGA version 4.0 (Tamura et al., 2007). The topology of the phylogenetic tree was evaluated by the bootstrap method of Felsenstein (1985) based on 1000 replicates.

Cells of strain Mer $29717^{\mathrm{T}}$ were Gram-stain-positive, nonmotile, aerobic to microaerobic cocci, approximately $0.7-0.9 \mu \mathrm{m}$ in diameter (Fig. 1). Colonies on ISP medium 2 after 2 weeks at $28{ }^{\circ} \mathrm{C}$ were circular, convex, pale yellow and usually $1.0 \mathrm{~mm}$ in diameter. The isolate grew on ISP medium 2 with up to $7 \% \mathrm{NaCl}$; optimum growth was observed in the absence of $\mathrm{NaCl}$. Growth was observed at $15-37^{\circ} \mathrm{C}$, with an optimum between 25 and $30{ }^{\circ} \mathrm{C}$. Other physiological properties are given in the genus and species descriptions.

The cell-wall peptidoglycan of strain Mer $29717^{\mathrm{T}}$ contained L-Lys, D-Ser, L-Ser, Gly, D-Glu and D-Ala in a molar ratio of $1.6: 1.4: 1.0: 0.4: 2.0: 0.9$, corresponding to peptidoglycan type A4 $\alpha$ of Schleifer \& Kandler (1972). Strain Mer $29717^{\mathrm{T}}$ contained MK- $8\left(\mathrm{H}_{2}\right)(52 \%)$ and $\mathrm{MK}-8\left(\mathrm{H}_{4}\right)(48 \%)$ as menaquinones. The cell-wall muramic acid was of the acetyl type. Mycolic acids were not detected. The polar lipids consisted of phosphatidylinositol, phosphatidylglycerol, diphosphatidylglycerol and one unidentified phospholipid (see Supplementary Fig. S1, available in IJSEM Online). Whole-cell sugars were galactose, mannose, rhamnose, ribose, glucose and arabinose. The $\mathrm{G}+\mathrm{C}$ content of the DNA of strain Mer $29717^{\mathrm{T}}$ was $68 \mathrm{~mol} \%$. The cellular fatty acid profile of strain Mer $29717^{\mathrm{T}}$ was dominated by $\mathrm{C}_{17: 1}$ cis-9, iso- $\mathrm{C}_{16: 0}, \mathrm{C}_{18: 1}$ cis- $9, \mathrm{C}_{17: 0}$, $\mathrm{C}_{19: 1}$ cis-10 and $\mathrm{C}_{16: 0}$ (Table 1).

The almost-complete 16S rRNA gene sequence (1524 nt) of strain Mer $29717^{\mathrm{T}}$ was determined. A BLAST search in GenBank and the EzTaxon server showed that strain Mer $29717^{\mathrm{T}}$ was related most closely to Yimella lutea YIM $45900^{\mathrm{T}}$ (95.1\% $16 \mathrm{~S}$ rRNA gene sequence similarity), Demetria terragena HKI $0089^{\mathrm{T}}(94.6 \%)$, Luteipulveratus mongoliensis MN07-A0330 ${ }^{\mathrm{T}}(94.6 \%)$ and Dermacoccus nishinomiyaensis DSM $20448^{\mathrm{T}}(94.7 \%)$. These results suggest that the isolate belongs within the family Dermacoccaceae. However, levels of $16 \mathrm{~S}$ rRNA gene sequence similarity to the type strains of species in the family were 92.2-95.1\%. Furthermore, phylogenetic trees reconstructed by the three tree-making algorithms revealed that strain Mer $29717^{\mathrm{T}}$ formed a distinct lineage within the family Dermacoccaceae (Fig. 2 and Supplementary Fig. S2).

At the time of writing, the family Dermacoccaceae comprises five genera, Demetria (Groth et al., 1997), Dermacoccus (Stackebrandt et al., 1995), Kytococcus (Stackebrandt et al., 1995), Luteipulveratus (Ara et al., 2010) and Yimella (Tang et al., 2010). Strain Mer $29717^{\mathrm{T}}$ could be differentiated from other genera of the family Dermacoccaceae based on a number of morphological and chemotaxonomic characteristics (Table 2). The cell-wall peptidoglycan of strain Mer $29717^{\mathrm{T}}$ contained L-Lys, D-Ser, L-Ser, Gly, D-Glu and D-Ala in a molar ratio of $1.6: 1.4: 1.0: 0.4: 2.0: 0.9$. Similar to members of the genera Demetria, Yimella and Luteipulveratus, strain Mer $29717^{\mathrm{T}}$ contains Ser in the peptidoglycan but it clearly differs from them by the absence of Asp. Strain Mer $29717^{\mathrm{T}}$ can also be distinguished from Dermacoccus and Kytococcus in that it has a different amino acid composition of the cell wall. In addition, strain Mer $29717^{\mathrm{T}}$ can be distinguished from the other genera in the family Dermacoccaceae by containing MK-8 $\left(\mathrm{H}_{2}\right)$ and MK-8 $\left(\mathrm{H}_{4}\right)$ as major menaquinones.

Other differential characteristics included phosphatidylinositol, phosphatidylglycerol, diphosphatidylglycerol and one unidentified phospholipid as total phospholipids. In addition, strain Mer $29717^{\mathrm{T}}$ contained galactose, mannose, rhamnose, ribose, glucose and arabinose as whole-cell

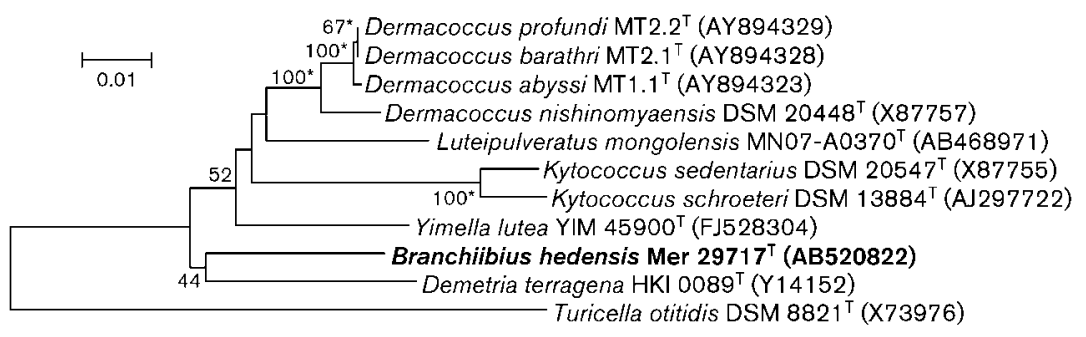

Fig. 2. Neighbour-joining tree showing the phylogenetic positions of strain Mer $29717^{\top}$ and related organisms, inferred from 16S rRNA gene sequence analyses. Bootstrap values $>50 \%$ (from 1000 bootstrap resamplings) are indicated. Asterisks indicate phyletic lines that were also recovered in the maximum-parsimony tree. Turicella otitidis DSM $8821^{\top}$ was used as an outgroup to define the root of the tree. Bar, 0.01 substitutions per nucleotide position. A maximumlikelihood tree is shown in Supplementary Fig. S2. 
Table 2. Differential morphological and chemotaxonomic features between strain Mer $29717^{\top}$ and members of the family Dermacoccaceae

Data for reference genera were taken from Groth et al. (1997) (Demetria), Stackebrandt et al. (1995) (unless indicated) (Dermacoccus and Kytococcus), Tang et al. (2010) (Yimella) and Ara et al. (2010) (Luteipulveratus). \pm , Weakly positive; v, variable; ND, no data available.

\begin{tabular}{|c|c|c|c|c|c|c|}
\hline Characteristic & Mer $29717^{T}$ & Demetria & Dermacoccus & Kytococcus & Yimella & Luteipulveratus \\
\hline Cell morphology & Coccoid & Coccoid or rods & Coccoid & Coccoid & Coccoid & $\begin{array}{c}\text { Coccoid to short } \\
\text { rods }\end{array}$ \\
\hline Colony colour & Pale yellow & White to pale yellow & Bright orange & $\begin{array}{c}\text { Deep buttercup } \\
\text { yellow or } \\
\text { cream-white }\end{array}$ & Orange & $\begin{array}{c}\text { Cream to bright } \\
\text { yellow }\end{array}$ \\
\hline Cell size $(\mu \mathrm{m})$ & $0.7 \times 0.9$ & $0.8 \times 1.2$ or $0.8 \times 3.0$ & $0.9 \times 1.6$ & $0.8 \times 1.1$ & $\begin{array}{c}0.7-0.9 \times 1.3 \\
-1.8\end{array}$ & $\begin{array}{c}0.5 \times 1.0 \text { to } 0.8 \\
\times 1.2\end{array}$ \\
\hline Nitrate reduction & + & - & $\mathrm{v}$ & V & + & - \\
\hline \multicolumn{7}{|l|}{ Hydrolysis of: } \\
\hline Gelatin & + & - & + & + & + & + \\
\hline Starch & - & + & - & - & - & \pm \\
\hline \multicolumn{7}{|l|}{ Conditions for growth } \\
\hline $\mathrm{NaCl}$ range $(\%, \mathrm{w} / \mathrm{v})$ & $0-7$ & $0-12$ & $0-7$ & $0-10$ & $0-8$ & $0-2$ \\
\hline $10{ }^{\circ} \mathrm{C}$ & - & $\mathrm{ND}$ & - & $\mathrm{ND}$ & - & + \\
\hline $37{ }^{\circ} \mathrm{C}$ & + & - & + & + & + & - \\
\hline $40{ }^{\circ} \mathrm{C}$ & + & - & $\mathrm{ND}$ & + & + & - \\
\hline \multicolumn{7}{|l|}{ API ZYM results } \\
\hline$\alpha$-Fucosidase & - & - & + & ND & - & \pm \\
\hline$\beta$-Glucosidase & + & - & + & ND & - & - \\
\hline Lipase (C14) & - & \pm & + & $\mathrm{ND}$ & - & - \\
\hline Trypsin & + & \pm & + & $\mathrm{ND}$ & + & + \\
\hline $\begin{array}{l}\text { Amino acid } \\
\text { composition of } \\
\text { peptidoglycan } \\
\text { (ratio) }\end{array}$ & $\begin{array}{l}\text { L-Lys (1.6), D-Ser } \\
(1.4) \text {, L-Ser (1.0), } \\
\text { Gly (0.4), D-Glu } \\
(2.0) \text {, D-Ala }(0.9)\end{array}$ & $\begin{array}{l}\text { L-Lys (0.8), D-Ala } \\
(0.8), \text { L-Ala }(1.0) \text {, } \\
\text { D-Asp (1.2), D-Glu } \\
(1.0), \text { L-Ser }(0.8)\end{array}$ & $\begin{array}{c}\text { Ala }(3.0) \text {, Ser }(0.9) \text {, Glu } \\
(2.3) \text {, Lys }(1.0)^{\star}\end{array}$ & $\begin{array}{l}\text { Ala (1.6), Gly } \\
(0.1) \text {, Glu (2.5), } \\
\text { Lys (1.0) } \dagger\end{array}$ & $\begin{array}{c}\text { Ala (1.6), Gly } \\
\quad(1.0), \text { Ser } \\
(0.7), \text { Asp } \\
(0.8), \text { Glu } \\
(1.0), \text { Lys } \\
(1.2)\end{array}$ & $\begin{array}{l}\text { L-Lys (0.8), Ala } \\
(2.7), \text { Asp (0.6), } \\
\text { Glu (1.0), Ser (0.9) }\end{array}$ \\
\hline $\begin{array}{l}\text { Major } \\
\text { menaquinone(s) }\end{array}$ & $8\left(\mathrm{H}_{2}\right), 8\left(\mathrm{H}_{4}\right)$ & $8\left(\mathrm{H}_{4}\right)$ & $7\left(\mathrm{H}_{2}\right), 8\left(\mathrm{H}_{2}\right), 9\left(\mathrm{H}_{2}\right)$ & $8,9,10$ & $8\left(\mathrm{H}_{4}\right)$ & $8\left(\mathrm{H}_{4}\right), 8\left(\mathrm{H}_{6}\right)$ \\
\hline Fatty acids $\neq$ & I, U, S, A & $\mathrm{S}, \mathrm{U}, \mathrm{A}, \mathrm{I}$ & S, A, I & S, A, I & $\mathrm{A}, \mathrm{I}$ & A, I, U \\
\hline Polar lipids $§$ & $\begin{array}{c}\text { PI, PG, DPG, } \\
\text { 1PL }\end{array}$ & $\begin{array}{c}\text { PI, PG, DPG, PE, } \\
\text { 2PL }\end{array}$ & DPG, PG, PI & DPG, PG, PI & $\begin{array}{l}\text { DPG, PI, Glu- } \\
\text { NU, PL }\end{array}$ & DPG, PG, PI \\
\hline $\begin{array}{l}\text { DNA G+C content } \\
(\mathrm{mol} \%)\end{array}$ & 68 & 66 & $66-71$ & $68-69$ & 65.8 & 68.2 \\
\hline
\end{tabular}

${ }^{\star}$ Data from Pathom-aree et al. $(2006 \mathrm{a}, \mathrm{b})$.

$\dagger$ Data from Kämpfer et al. (2009).

$¥$ ॠ, Iso-branched; U, unsaturated; S, straight-chain saturated; A, anteiso-branched. Data from Kämpfer et al. (2009) and Stackebrandt et al. (1995). §DP, Diphosphatidylglycerol; PE, phosphatidylethanolamine; PI, phosphatidylinositol; PG, phosphatidylglycerol; Glu-NU, glucosaminecontaining phospholipid; PL, unidentified phospholipid.

sugars. Mycolic acids were not present. The fatty acid profile was characterized by the occurrence of large amounts of unsaturated straight-chain components $\left(\mathrm{C}_{17: 1}\right.$ cis-9 and $\mathrm{C}_{18: 1}$ cis-9) and one iso-branched-chain fatty acid (iso- $\mathrm{C}_{16: 0}$ ) (Table 1 ). The $\mathrm{G}+\mathrm{C}$ content of the DNA of strain Mer $29717^{\mathrm{T}}$ was $68 \mathrm{~mol} \%$. Therefore, on the basis of differential chemotaxonomic characteristics (Table 2 ), in particular the amino acid composition of the peptidoglycan, in combination with menaquinone components MK- $8\left(\mathrm{H}_{4}\right)$ and MK- $8\left(\mathrm{H}_{6}\right)$, strain Mer $29717^{\mathrm{T}}$ can be distinguished clearly from members of the family Dermacoccaceae.

The closest phylogenetic neighbour to strain $29717^{\mathrm{T}}$ is Demetria terragena HKI $0089^{\mathrm{T}}(94.6 \%$ 16S rRNA gene sequence similarity), the latter differing in the amino acid composition of the peptidoglycan, predominant menaquinones and major fatty acids, as well as physiological, cultural and biochemical characteristics (Tables 1 and 2). Furthermore, morphological differences distinguish strain 
Mer $29717^{\mathrm{T}}$ from members of the genus Demetria. Obvious differences in chemotaxonomic, morphological and physiological properties were also found between strain Mer $29717^{\mathrm{T}}$ and Yimella lutea (Table 2). Therefore, on the basis of the distinct phylogenetic position of the novel isolate within the family Dermacoccaceae, and differences in physiological, morphological and biochemical characteristics, we propose that strain Mer $29717^{\mathrm{T}}$ represents a novel species of a new genus, for which the name Branchiibius hedensis gen. nov., sp. nov. is proposed.

\section{Description of Branchiibius gen. nov.}

Branchiibius [Bran.chi.i.bi' us. L. pl. n. branchiae the gills of fish; N.L. masc. n. bius (from Gr. masc. n. bios) life; N.L. masc. n. Branchiibius a life existing in gills of fish].

Cells are Gram-stain-positive, coccoid $(0.7 \times 0.9 \mu \mathrm{m})$, halotolerant, non-motile and aerobic to microaerobic. They do not form endospores. Colonies are circular, convex, entire, smooth and pale yellow. The cell-wall peptidoglycan contains L-Lys, D-Ser, L-Ser, Gly, D-Glu and D-Ala. The acyl type of the muramic acid in the peptidoglycan is acetyl. Menaquinones are $\mathrm{MK}-8\left(\mathrm{H}_{2}\right)$ and MK-8 $\left(\mathrm{H}_{4}\right)$. Phospholipids are phosphatidylinositol, phosphatidylglycerol, diphosphatidylglycerol and one unidentified phospholipid, and whole-cell sugars are galactose, mannose, rhamnose, ribose, glucose and arabinose. Mycolic acids are absent. The major fatty acids are $\mathrm{C}_{17: 1}$ cis-9, $\mathrm{C}_{18: 1}$ cis-9 and iso- $\mathrm{C}_{16: 0}$. Phylogenetically, the genus is a member of the family Dermacoccaceae and the type species is Branchibius hedensis.

\section{Description of Branchiibius hedensis sp. nov.}

Branchibius hedensis sp. nov. (he.den'sis. N.L. masc. adj. hedensis of or belonging to Heda, a town in Shizuoka prefecture, Japan, from where the codfish providing the source of the type strain was collected).

Morphological, chemotaxonomic and general characteristics are as given above for the genus. In addition, colonies grown on ISP medium 2 after 2 weeks at $28{ }^{\circ} \mathrm{C}$ are $1.0 \mathrm{~mm}$ in diameter. Good growth occurs on HVA medium and ISP media 2, 3 and 6. Optimal growth occurs at $20-37{ }^{\circ} \mathrm{C}$; no growth occurs at $50{ }^{\circ} \mathrm{C}$. Growth occurs in the presence of $\mathrm{NaCl}$ at concentrations up to $7.0 \%$. Nitrates are reduced. Melanin is not produced. Gelatin is hydrolysed but coagulation of milk is not observed. Starch is hydrolysed weakly. Decomposes calcium malate and cellulose weakly. Hydrogen sulfide is not produced. According to API ZYM enzyme assays, positive for esterase (C4), esterase lipase (C8), leucine arylamidase, valine arylamidase, cystine arylamidase, trypsin, acid phosphatase, phosphohydrolase, $\beta$-galactosidase, $\alpha$-glucosidase, $\beta$-glucosidase and $N$-acetyl- $\beta$-glucosaminidase. Utilizes Dglucose, D-fructose, sucrose and D-mannitol as carbon sources, but not L-arabinose, D-xylose, L-rhamnose, raffinose or inositol. In addition to the major fatty acids listed for the genus, minor amounts of $\mathrm{C}_{17: 0}, \mathrm{C}_{16: 0}, \mathrm{C}_{19: 1}$ cis-10, anteiso- $\mathrm{C}_{18: 0}, \mathrm{C}_{15: 0}, 10$-methyl $\mathrm{C}_{17: 1}$ and 10-methyl $\mathrm{C}_{17: 0}$ are also present. The DNA G $+\mathrm{C}$ content of the type strain is $68 \mathrm{~mol} \%$.

The type strain, Mer $29717^{\mathrm{T}}\left(=\mathrm{DSM} 22951^{\mathrm{T}}=\mathrm{NBRC}\right.$ $\left.106121^{\mathrm{T}}\right)$, was isolated from the branchia of a Japanese codling, Physiculus japonicus.

\section{Acknowledgements}

We thank the Fisheries Cooperative Association of Heda, Shizuoka, Japan, for provision of fishes. We are also grateful to Professor J. P. Euzéby for his advice on the nomenclature of the new genus.

\section{References}

Altschul, S. F., Gish, W., Miller, W., Myers, E. W. \& Lipman, D. J. (1990). Basic local alignment search tool. J Mol Biol 215, 403-410.

Ara, I., Yamamura, H., Tsetseg, B., Daram, D. \& Ando, K. (2010). Luteipulveratus mongoliensis gen. nov., sp. nov., an actinobacterial taxon in the family Dermacoccaceae. Int J Syst Evol Microbiol 60, 574579.

Becker, B., Lechevalier, M. P., Gordon, R. E. \& Lechevalier, H. A. (1964). Rapid differentiation between Nocardia and Streptomyces by paper chromatography of whole-cell hydrolysates. Appl Microbiol 12, 421-423.

Chun, J., Lee, J. H., Jung, Y., Kim, M., Kim, S., Kim, B. K. \& Lim, Y.-W. (2007). EzTaxon: a web-based tool for the identification of prokaryotes based on $16 \mathrm{~S}$ ribosomal RNA gene sequences. Int J Syst Evol Microbiol 57, 2259-2261.

Felsenstein, J. (1981). Evolutionary trees from DNA sequences: a maximum likelihood approach. J Mol Evol 17, 368-376.

Felsenstein, J. (1985). Confidence limits on phylogenies: an approach using the bootstrap. Evolution 39, 783-789.

Fenical, W. \& Jensen, P. R. (2006). Developing a new resource for drug discovery: marine actinomycete bacteria. Nat Chem Biol 2, 666673.

Fiedler, H. P., Bruntner, C., Bull, A. T., Ward, A. C., Goodfellow, M., Potterat, O., Puder, C. \& Mihm, G. (2005). Marine actinomycetes as a source of novel secondary metabolites. Antonie van Leeuwenhoek 87, 37-42.

Fitch, W. M. (1971). Towards defining the course of evolution: minimum change for a specific tree topology. Syst Zool 20, 406-416.

Groth, I., Schumann, P., Rainey, F. A., Martin, K., Schuetze, B. \& Augsten, K. (1997). Demetria terragena gen. nov., sp. nov., a new genus of actinomycetes isolated from compost soil. Int J Syst Bacteriol 47, 1129-1133.

Hayakawa, M. \& Nonomura, H. (1987). Humic acid-vitamin agar, a new medium for the selective isolation of soil actinomycetes. J Ferment Technol 65, 501-509.

Jensen, P. R., Mincer, T. J., Williams, P. G. \& Fenical, W. (2005). Marine actinomycete diversity and natural product discovery. Antonie van Leeuwenhoek 87, 43-48.

Kämpfer, P., Martin, K., Schäfer, J. \& Schumann, P. (2009). Kytococcus aerolatus sp. nov., isolated from indoor air in a room colonized with moulds. Syst Appl Microbiol 32, 301-305.

Katayama-Fujiwara, Y., Komatsu, Y., Kuraishi, H. \& Kaneko, T. (1984). Estimation of DNA base composition by high performance 
liquid chromatography of its nuclease $\mathrm{P}_{1}$ hydrolysate. Agric Biol Chem 48, 3169-3172.

Katoh, K., Suzuki-Onozaki, A., Ohta, T., Ebine, H., Kumagai, M., Fujimoto, M. \& Kuninaka, A. (1983). Microbiological identification of single cell proteins based on DNA-GC contents. Part II. Chemical determination of DNA-GC contents. Rept Natl Food Res Inst 43, 7989.

Kawasaki, Y., Nozawa, Y. \& Harada, K. (2007). Elution behavior of diaminopimelic acid and related diamino acids using the advanced Marfey's method. J Chromatogr A 1160, 246-253.

Kimura, M. (1980). A simple method for estimating evolutionary rates of base substitutions through comparative studies of nucleotide sequences. J Mol Evol 16, 111-120.

Lam, K. S. (2006). Discovery of novel metabolites from marine actinomycetes. Curr Opin Microbiol 9, 245-251.

Miller, L. T. (1982). Single derivatization method for routine analysis of bacterial whole-cell fatty acid methyl esters, including hydroxy acids. J Clin Microbiol 16, 584-586.

Minnikin, D. E., Alshamaony, L. \& Goodfellow, M. J. (1975). Differentiation of Mycobacterium, Nocardia, and related taxa by thin-layer chromatographic analysis of whole-organism methanolysates. J Gen Microbiol 88, 200-204.

Minnikin, D. E., O’Donnell, A. G., Goodfellow, M. J., Alderson, G., Athalye, M., Schaal, A. \& Parlett, J. H. (1984). An integrated procedure for the extraction of bacterial isoprenoid quinones and polar lipids. J Microbiol Methods 2, 233-241.

Pathom-aree, W., Nogi, Y., Sutcliffe, I. C., Ward, A. C., Horikoshi, K., Bull, A. T. \& Goodfellow, M. (2006a). Dermacoccus abyssi sp. nov., a piezotolerant actinomycete isolated from the Mariana Trench. Int J Syst Evol Microbiol 56, 1233-1237.

Pathom-aree, W., Nogi, Y., Ward, A. C., Horikoshi, K., Bull, A. T. \& Goodfellow, M. (2006b). Dermacoccus barathri sp. nov. and Dermacoccus profundi sp. nov., novel actinomycetes isolated from deep-sea mud of the Mariana Trench. Int J Syst Evol Microbiol 56, 2303-2307.
Saitou, N. \& Nei, M. (1987). The neighbor-joining method: a new method for reconstructing phylogenetic trees. Mol Biol Evol 4, 406-425.

Schleifer, K. H. \& Kandler, O. (1972). Peptidoglycan types of bacterial cell walls and their taxonomic implications. Bacteriol Rev 34, 407-477.

Shirling, E. B. \& Gottlieb, D. (1966). Methods for characterization of Streptomyces species. Int J Syst Bacteriol 16, 313-340.

Stackebrandt, E. \& Schumann, P. (2000). Description of Bogoriellaceae fam. nov., Dermacoccaceae fam. nov., Rarobacteraceae fam. nov. and Sanguibacteraceae fam. nov. and emendation of some families of the suborder Micrococcineae. Int J Syst Evol Microbiol 50, 1279-1285.

Stackebrandt, E., Koch, C., Gvozdiak, O. \& Schumann, P. (1995). Taxonomic dissection of the genus Micrococcus: Kocuria gen. nov., Nesterenkonia gen. nov., Kytococcus gen. nov., Dermacoccus gen. nov., and Micrococcus Cohn 1872 gen. emend. Int J Syst Bacteriol 45, 682692.

Tamura, K., Dudley, J., Nei, M. \& Kumar, S. (2007). MEGA4: molecular evolutionary genetics analysis (MEGA) software version 4.0. Mol Biol Evol 24, 1596-1599.

Tang, S.-K., Wu, J.-Y., Wang, Y., Schumann, P. \& Li, W.-J. (2010). Yimella lutea gen. nov., sp. nov., a novel actinobacterium of the family Dermacoccaceae. Int J Syst Evol Microbiol 60, 659-663.

Thompson, J. D., Gibson, T. J., Plewniak, F., Jeanmougin, F. \& Higgins, D. G. (1997). The CLUSTAL_X windows interface: flexible strategies for multiple sequence alignment aided by quality analysis tools. Nucleic Acids Res 25, 4876-4882.

Uchida, K. \& Aida, K. (1977). Acyl type of bacterial cell wall: its simple identification by colorimetric method. J Gen Appl Microbiol 23, 249260.

Weisburg, W. G., Barns, S. M., Pelletier, D. A. \& Lane, D. J. (1991). 16 S ribosomal DNA amplification for phylogenetic study. J Bacteriol 173, 697-703.

Yang, X., Zhao, Y., Wang, Q., Wang, H. \& Mei, Q. (2005). Analysis of the monosaccharide components in Angelica polysaccharides by high performance liquid chromatography. Anal Sci 21, 1177-1180. 